No. $10-17$

\title{
The Financial Structure of Startup Firms: The Role of Assets, Information, and Entrepreneur Characteristics
}

\author{
Paroma Sanyal and Catherine L. Mann
}

\begin{abstract}
:
Using the Kauffman Firm Survey, we examine how characteristics of a startup's assets, information about the startup, and entrepreneur attributes relate to financial structure at inception. Startups with more physical assets or those where the entrepreneurs have other similar businesses are more likely to use external debt in the financial structure since these assets have a high liquidation value. Startups with human capital embodied in the entrepreneur or intellectual property assets have a lower probability of using debt, consistent with the higher asset specificity and lower collateral value of these assets. Startups characterized as small, unincorporated, solo, first-time, or home-office-based are more likely to be financed by self, family and friends, and importantly through credit cards, as these have both highly specific assets and information opacity. More educated founders and non-African American founders are more likely to be financed by external sources. Controlling for other attributes of the startup, the financial structure of women-owned startups does not differ from that of other startups. Hi-tech startups' financial structure differs significantly from that of startups in other business sectors.
\end{abstract}

Keywords: capital structure, asset specificity, information opacity, startup financing JEL Classifications: G32, L26

Paroma Sanyal is an assistant professor of economics at Brandeis University. Catherine L. Mann is the Barbara and Richard M. Rosenberg Professor of Global Finance in the International Business School at Brandeis University and a visiting scholar in the research department of the Federal Reserve Bank of Boston. Their e-mail

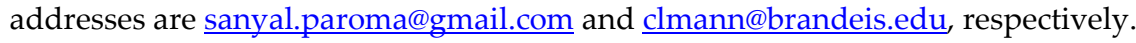

This paper, which may be revised, is available on the web site of the Federal Reserve Bank of Boston at http://www.bos.frb.org/economic/wp/index.htm.

We would like to thank the participants of the 2010 Entrepreneurial and Innovation Conference, 2010 IIOC, 2010 Western Economics Association, Bentley College Economics Seminar, the Kauffman webinar, and the Brandeis University Economics Seminar for helpful comments. Particular thanks go to Alicia Robb for her continued help and K. Krisnamurthy for his insightful comments. All errors are ours alone.

The views expressed in here are those of the authors and do not necessarily reflect the views of the Federal Reserve Bank of Boston or the Federal Reserve System.

This version: December 2010 


\section{Introduction}

Little is known about the financial structure of startup firms. Theoretical research and most empirical investigations have focused on large established firms, which can tap an array of financial sources, such as stock equity or commercial paper, a situation quite different from that facing small firms. Most empirical research on small firms has focused on ongoing firms. Yet, recent research has revealed the importance of startups for economic vibrancy and job creation. (Haltiwanger, Jarmin, and Miranda, 2010; Kane, 2010; Stangler, 2010). During times of financial crisis, such as 2008-20010, it is difficult to determine whether credit conditions affect startup activity without having a benchmark assessment of the financial structure of startup firms during more normal credit conditions. This paper draws on the theoretical and empirical literature of the financial structure of established firms to develop insights on startups, which are then examined using the Kauffman Firm Survey.

Our sample of startups is drawn from the Kauffman Firm Survey (KFS), where 98 percent of the businesses have fewer than 25 employees. ${ }^{1}$ We investigate the startups that are new in 2004, the first year of the survey. The survey detail on these firms is impressive, including detailed data on sector of business activity, financial structure, entrepreneur, and location characteristics. ${ }^{2}$ Before the KFS survey, such truly new and small business entities were little studied.

Consistent with theoretical underpinnings based on asset specificity, we find that startups with more physical assets or those where the owners have other businesses are more likely than other startups to have external debt in the financial structure, since these assets have a higher liquidation value. On the other hand, all else being equal, startups with higher human capital embodied in the entrepreneur or more intellectual property assets have a lower probability of using debt, consistent with the higher asset specificity and lower collateral value of these assets.

\footnotetext{
${ }^{1}$ Usually, researchers classify small firms as entities that have fewer than 500 employees (Acs and Audretsch,1989 [1])

${ }^{2}$ Survival and performance data are available in the follow-on surveys.
} 
In terms of information opacity, startups located in the entrepreneur's home are the most opaque and their financial structure is dominated by credit card debt. Team-run startups and those with serial entrepreneurs are more likely than other startups to have internal and external equity in their financial structure, consistent with their greater personal resources and available information about the principals.

In terms of owner attributes, older and more educated entrepreneurs are more likely to use debt financing, while African-American entrepreneurs are more likely to use their own resources to finance their businesses. Controlling for other attributes of the startup, the financial structure of women-owned startups does not differ from that of male-owned startups.

Regional factors and local conditions relate to the financial structure of startups. Areas with better-educated resident populations are more likely to finance startups using internal debt. Startups in innovative states and states with higher venture capital (VC) activity have a greater probability of external equity in their financial structure. Startups in larger states have a higher probability of bank loans in their financial structure at inception.

We also find that there are significant dissimilarities in the financial structure between hi-tech startups and startups in other sectors. Some of the biggest differences can be traced to the relationship between financial structure and race, citizenship, and business knowledge (for example, having related businesses in the same sector).

The next section briefly reviews the literature and develops hypotheses on the expected relationships between the financial structure of the startup firm and characteristics of its assets, information, and entrepreneurs. Section 3 gives an overview of the Kauffman Firm Survey and our variable definitions and construction. Section 4 presents our estimation methodology and results. Section 5 concludes.

\section{Literature Review}

Financial structure is central to a firm's business strategy and has important implications for firm behavior. In extensions of Modigliani-Miller (1958), theoretical analyses of large established firms have addressed how the degree of asset specificity (asset value at bankruptcy) and information opacity (aligning manager and share-holder interest) influences governance 
and financial structure. Established-firm theory finds that, on the one hand, firms with highly specific assets (low liquidation value at bankruptcy) should have a higher proportion of equity relative to debt, since stockholders in principle can exercise greater control over the operations of the firm, whereas debt-holders cannot appropriate the highly specific assets. On the other hand, under conditions of information opacity about managers' activities, after internal resources, the firm should use bank debt, which disciplines management, and lastly equity, where ensuring the alignment of interests between managers and shareholders is more difficult. Our question: does the ranking with regard to internal funds, external debt, and external equity that comes from established-firm theory play out for startups, which have different asset and information characteristics as well as a different set of financial sources?

Previous research points out that, in the case of startups, there are no ongoing operations and no track record by which to judge the firm. This information opacity makes external financing more difficult to obtain at the nascent stages (Bruno and Tyebjee, 1985; Manigart and Struyf, 1997; Cassar, 2004; Avery et al., 1998; Berger and Udell, 1995; Paulson and Townsend, 2004). A startup's potential external equity investors (such as angel or venture capital) may have limited information about the founder (unless s/he is a serial entrepreneur) or the prospects for the enterprise and may therefore demand a high ownership stake for a given financial outlay. From the standpoint of the owner-founder, internal finance is preferred, followed by external debt such as bank financing, and only lastly would the founder use expensive external equity where s/he has to give up a large ownership stake (Berger and Udell, 1995; Scholtens, 1999; Huyghebaert and Gucht, 2007).

However, these predictions based on information opacity are qualified by the characteristics of the assets of most startups. In small startups the entrepreneur not only supplies managerial expertise, but also provides financial, knowledge, and human capital to the firm (Hart and Moore, 1995; Audretsch et al., 2009). Such specific human capital may not be easily transferable to alternative uses, which compounds the information opacity problem (Klein at. al. 1978; Williamson, 1975, 1985; Balakrishna and Fox, 1993; Kochhar, 1996; VincenteLorente, 2001). The 'inalienable' nature of human capital of the entrepreneur (Hart and Moore, 1994) exacerbates the tension between debt holders and the owner because the owner can 
threaten to walk away. Therefore, firms with a high degree of asset specificity should be financed primarily by the entrepreneur's own resources, followed by external equity such as venture capital, and last by external debt.

Insights gleaned from theory suggest that startups would use internal funds first, followed by external resources, with the predictions on the external debt-equity mix unclear and dependent on the relative importance of asset specificity and information opacity. However, despite this theoretical preference for internal finance, Berger and Udell (2003) reveals the importance of debt financing for young firms in the United States, including highgrowth startups. ${ }^{3}$ Therefore, in practice, resource constraints faced by the entrepreneur mean that startups are likely to rely primarily on external financing of one sort or another. Our analysis using the detailed financial data in the KFS helps tease out the relative importance of internal equity and debt versus external equity and debt in the financial structure of startups, as well as the type of external debt.

Outside the issues of asset specificity, information opacity, and financial constraints, substantial empirical work focuses on the relationship between financial structure and entrepreneur characteristics such as their education (Bates, 1990; Cressy, 1996; Chandler and Hanks, 1998; Baum and Silverman, 2004; Astebro et al., 2005), race and ethnic ties (Bates, 1997a, b; Smallbone et al., 2003), gender (Fay and Williams, 1991; Verheul and Hurik, 2001), strategic alliances and networks (Petersen and Rajan, 1994; Coleman, 2000; Baum and Silverman, 2004; Chang, 2004), and experience of the founding team (Delmar and Shane, 2006). Using the KFS allows us to examine these entrepreneur characteristics in conjunction with financial structure. With regard to race and gender, the KFS allows us to examine whether the financial structure of African-American and women-owned firms differs from that of other startups, and specifically to examine whether they have less external funding.

\footnotetext{
${ }^{3}$ They show that for startups less than two years old, debt accounts for 52 percent of capital structure, which is in line with the 50 percent debt found for all firms. Additionally, even high-growth firms have as much as 33 percent debt by the time they go public.
} 
The contribution of this paper arises from the fact that the KFS allows us to look at the financial structure of firms at inception and compare that to both the theories of established firms and the empirical investigations of ongoing small firms.

We expect:

$H$ 1: When information about the activities of the startup are particularly opaque, internal finance is used, followed by external bank debt, and last, by external equity

H2: When assets of the startup are highly specific, internal finance is used, followed by external equity such as venture capital, and last, by external bank debt.

H3: African-American and/or women-owned startups do not use external sources of funds.

\section{Kauffman Firm Survey and Variable Construction}

The primary data are obtained from the Kauffman Firm Survey (KFS), which tracks from year-to-year a panel of about 5,000 businesses. Each business has a unique identification number, and the original survey posed more than 1,400 questions to each firm in the survey, including detailed questions on financial structure, owner and founder characteristics, business and innovation activity, and location. ${ }^{4}$ Because we are interested in the financial structure of the startup at inception, we examine the firms in their founding year in $2004 .^{5}$

The KFS new venture is defined as "a new independent business that was created by a single person or a team of people; the purchase of an existing business; or the purchase of a

\footnotetext{
${ }^{4}$ The KFS firms were drawn from all new businesses that were started in 2004 (and did not die within one year) as represented by the 237,843 enterprises in the Dunn and Bradstreet. The data were partitioned into six strata based on the industry technological category and the gender of the owner or CEO of the business. The industry technology classification ensured that a large sample of high-technology new businesses was represented in the KFS. The gender category ensured that women-owned businesses were sufficiently represented in the final sample, although such businesses were not oversampled. The weighted response rate (after including the sample weights) was 42.9 percent. See Kauffman Firm Survey 2005/2006: Baseline/First Follow-up (Scott Shane, Alicia Robb, Mathematica Policy Research Institute) for a detailed construction of the sampling weights and industry technological categories.

5 The latest survey (third follow-up) was released in March 2009 and contains many additional variables such as the credit risk of the business and the source of competitive advantage as identified by the entrepreneur, as well as information about performance and survival.
} 
franchise." 6 We consider only true startups, not purchased or franchise firms, yielding our sample of 4,201 startups from the total KFS new venture total of 4,630.

The KFS has detailed data (about a dozen different categories) on the types and amount of financing. The grossest disaggregation distinguishes between debt and equity in the financial structure. Along these lines, summary statistics for the 2004 sample (reported in Table 1A) show that for the average startup, 64 percent $^{7}$ of financing at inception is internal equity (primarily the entrepreneur's own resources), 30 percent is external loans, and the rest is made up of loans from friends and family and external equity financing. Compared with previous work on small firms (Berger and Udell, 2003) this suggests a much greater role for internal resources at startup than for young firms with ongoing operations. However, there is significant variation around these averages and this gross distinction between debt and equity does not take advantage of the KFS detail.

\subsection{Financial Structure Variables}

The rich detail in the KFS allows a deeper investigation of financial structure. Since most firms are financed primarily by only one type of finance, we use discrete variables (for example, the binary 0,1 ) when describing financial structure for each firm. ${ }^{8}$ (See Table 1B).

- Internal equity: 1 when the equity is entirely (or primarily) owned by entrepreneur/owners, their spouses and family, and/or by the employees of the company. About 26 percent of startups use internal equity as the primary method financing.

\footnotetext{
${ }^{6}$ Kauffman Firm Survey 2005/2006: Baseline/First Follow-up (Scott Shane, Alicia Robb, Mathematica Policy Research Institute). See also: http://www.kauffman.org/uploadedFiles/kfs_fourth_040709.pdf

${ }^{7}$ Figure is derived from 68 percent internal financing times 93.5 percent internal equity.

${ }^{8}$ Empirical work on established firms often uses the share of different types of financing instead of the $0-1$ binary choice. However, for the startup financial data, the 0-1 choice variable is superior because some of the shares are small while others are at such extremes that there would not be a normal distribution for the share variable. Nevertheless, in 80 percent of the sample, there is a mix of finance used at startup inception. To investigate the robustness of our results to alternative cut-offs for the binary choice, we considered cutoffs ranging from 75 to 95 percent. That is, the internal equity dummy takes the value 1 if the share of internal equity financing was greater than 75, 80, 85, 90 or 95 percent. Robustness checks show that our results are unaffected by the choice of cutoff. For the financial structure index used in the reported regressions we use the 75 percent cutoff.
} 
- Internal debt: 1 when the entrepreneur takes loans from family, and/or employees, or borrows from other personal sources. About 3 percent of firms use this type of financing.

- External debt: 1 when the business takes loans from banks, the government, business loans from business credit cards, other businesses, and/or from other sources. Seventy percent of startups use external debt to start their business. Of this external debt used to fund startups, 58 percent of the value of external debt is credit card debt, 5.6 percent is bank debt, and the rest is loans from government and other sources.

- External equity: 1 when equity financing is obtained from angels, other businesses, government, venture capital, and/or other sources. Approximately 1.4 percent of ventures use external equity financing in their initial year of operation.

Because external debt is so important, and because the decomposition of external debt into credit card and bank loans is important from a policy perspective, we also examine financial structure decomposed six ways:

- Owner resources: 1 when the equity is entirely (or primarily) owned by entrepreneur/owners

- Other internal resources: 1 when equity is owned by spouses and family, or by the employees of the company, and when an entrepreneur takes loans from family, and/or employees, or borrows from other personal sources.

- External debt-credit cards: 1 when the business is primarily funded by credit cards

- External debt-bank loans: 1 when the business is primarily funded by bank loans

- External debt-other: 1 when the business in primarily funded by other business and government sources.

- External equity: 1 when equity financing is obtained from angels, other businesses, government, venture capital, and/or other sources

\subsection{H1 and Measures of Information Opacity}

H1 implies that the greater is information opacity in a startup, the greater is the share of internal finance, with external debt such as bank financing next, and external equity the least 
used. To test this hypothesis we create three measures of information opacity: whether the firm operates from a home office, whether it is run by a team, and whether it is started by a serial entrepreneur. (See Table 1C.)

- Home office dummy: 1 when the venture is based in the home of the founder. Fifty-nine percent of startups are located at the residence of the entrepreneur.

- Team-run business: 1 when there are two or more active owners. Twenty-nine percent of startups are run by teams.

- Serial entrepreneurship: the total number of new ventures started by the owners of this venture. This measure varies between 0 and $140^{\circ}$ for the entire sample; on average, owners have started 1.4 new businesses.

Startups that lease an office provide enough information to rent commercial real estate. Serial entrepreneurs have a track record. Firms with multiple owners may have greater personal resources and, therefore, less need for other financial resources; but with more owners, at least one might be known to the financial community, mitigating the information opacity problem. Therefore, based on H1, startups operating from a home office, that are run by solo and/or firsttime entrepreneurs are likely to have the greatest information problems. For these startups, internal resources are likely to dominate financial structure, followed by external debt and very little external equity.

\subsection{Measures of Asset Specificity}

$\mathrm{H} 2$ implies that the greater is asset specificity in startups, the higher is the share of internal finance, followed by external equity such as equity from angels/venture capitalists, and finally by external debt. To test this hypothesis, we create five measures of asset specificity spanning both specific human capital, and intangible and tangible assets.

\footnotetext{
${ }_{9}^{9}$ Each business may have anywhere between 1 and 14 owners. This is the total number of businesses started by all the owners in aggregate.
} 
- Business knowledge: the number of businesses owned by all the entrepreneurs (who are also managers of the business $)^{10}$ in the same industry as this current venture. A majority of the entrepreneurs do not own other businesses in the same industry, although there is a wide dispersion, with some entrepreneurs owning up to six businesses in the same industry. This variable measures knowledge of the business sector (human capital), but it may also proxy for the availability of other business assets that could be used as collateral (tangible capital).

- Industry experience: total years of work experience of the entrepreneurs (who are also managers of the business) in the same industry as this current venture. ${ }^{11}$ The total work experience of all the entrepreneurs is between zero and 150 years, the larger number being for startups with a large number of owners. On average, entrepreneurs in firms have 14 to 17 years of work experience in the same industry.

- Tangible assets: cash on hand, and the value of buildings, machinery, and other property owned by the firm. Tangible assets can serve as collateral for obtaining loans from external sources and can have relatively high liquidation value compared with intangibles.

- Intellectual property: Total units of intellectual property (IP) owned by the venture: patents, copyrights, and trademarks. The distribution of IP varies between 0 and 103 , with an average firm holding about 1.5 units.

- RED personnel: the share of employees engaged in research and development (R\&D). In 2004, the average startup had 38 percent of employees engaged in R\&D.

\footnotetext{
${ }^{10}$ We include the business experience of the owners as a specific asset only if the entrepreneurs are also the managers or operators of the business. Otherwise, if they hire a manager, the human capital of the entrepreneur may not be important for the success of the business.

${ }^{11}$ As alternative measures of specific human capital, we have used the number of businesses and work experience of the primary owner, the mean number of businesses and work experience of all the owners; the results in our econometric estimates are unaltered.
} 
Tangible assets have high liquidation value in bankruptcy. Other businesses owned by the entrepreneur may be pledged as collateral or their retained earnings used to finance the new firm. The value of intellectual property and the activities of R\&D personnel, on the other hand, are less certain. If the firm owns patents that can be licensed out or sold to other firms, then such an asset would have low specificity and potentially high liquidation value. But, for most of our sample, IP consists of trademarks and copyrights that are particular to a venture and that may be valuable as ongoing assets, but would have low liquidation value.

Following H2, we expect startups with high amounts of human capital to be financed primarily by internal sources, and specifically by internal equity. We expect firms with a high proportion of tangible assets or access to other businesses to have a preponderance of external financing, and within that to use debt financing rather than equity financing. We expect firms with a high proportion of intangible assets to have more internal financing, followed by external equity, and then external debt.

\subsection{Entrepreneur Attributes}

H3, which is derived from other empirical work, implies that African-American and/or women-owned startups do not use external sources of funds. To test this hypothesis we use the rich array of entrepreneur characteristics in the KFS. ${ }^{12}$

o Black primary owner: 1 when the main owner is of African-American descent. Eight-and-ahalf percent of startups in the KFS sample have African-American owners.

o Woman primary owner: 1 if the main owner is a woman. Twenty-six percent of startups in the KFS sample have a woman as the primary owner.

\footnotetext{
12 One characteristic of owners and startups that is not available in the KFS dataset is owner wealth. Wealth of the owners is an important underpinning of financial structure and it is unfortunate that we lack this information. We attempt to get at this aspect through the variables measuring startup characteristics in the next sub-section.
} 
o Age of the primary owner: Measures general life experience and potentially more extensive business networks. The average age of the entrepreneur in our sample is about 45 years, although the range of ages varies between 17 and 87 years.

o Founder education: 1 when the primary owner has some college-level education. ${ }^{13}$ In the KFS sample, about 60 percent of entrepreneurs have some higher education.

o U.S. citizen primary owner: 1 when the entrepreneur is a U.S. citizen. Approximately 96 percent of entrepreneurs in the KFS sample are U.S. citizens.

From the previous literature we expect businesses owned by women and African-Americans to have greater difficulty in obtaining all forms of external financing, and therefore we expect to observe a preponderance of internal source financing, such as funding from the founder, friends, and family. With regard to citizenship, the tightening of credit regulations ('know your customer') after September 11, 2001 may mean that U.S. citizens will be relatively more able to access bank loans than non-citizens. On the other hand, non-U.S. citizens may have tighter networks, which can help with financing (Saxenian).

Following H3, we expect non-Black, non-woman startups; and startups with older founders, more education, and U.S. citizenship, to have better credit market access, and therefore a higher likelihood of having external finance dominate in the financial structure of the startup.

\subsection{Venture, Industry, and Spatial Controls}

In our sample of startups, there is significant variation in the concentration of startups by state and industry. By location, 11 percent of the ventures are located in California, followed by 7.6 percent in Texas, 5 percent in Michigan and Florida, and 4.5 percent in New York. By industry, 25.7 percent of businesses are concentrated in Professional, Scientific or Technical Services, 11 percent in Primary Metal Manufacturing, about 8 to 9 percent each in Construction,

\footnotetext{
${ }^{13}$ We also constructed alternative measures, such as a dummy for any of the owners having some college experience, or any of them having graduate degrees. In our econometric specification the results were very similar to those presented.
} 
Administrative and Support and Waste Management and Remediation Services and Other Services, and another 5.6 percent in Retail Trade.

We use various venture, industry, and state demographic and economic data as controls. We match these data with the KFS data by using the year, NAICS code, and state variable. To avoid endogeneity, we lag the state-level variables.

- Size: Number of employees in the startup year. This measure ranges from 0 to 1,100 . On average, most firms have two employees, with the median firm having only one employee.

- Incorporated company: 1 when the startup is a limited liability company, a subchapter Scorporation, a C-corporation, a general partnership, or a limited partnership company. In our sample about 65 percent are incorporated firms.

o Hi-Tech Industry: 1 when the firm is classified as one of the 6-digit, hi-tech NAICS sectors. Five hundred and eighty-seven (or about 14 percent of the sample) are hi-tech startups using this definition. ${ }^{14}$

o Highly educated population: log value of the number of graduate students in the state from National Science Foundation's Science and Technology Indicators.

o Innovative capacity: R\&D intensity in a state. ${ }^{15}$

- State size: total population from Bureau of Labor Statistics.

o VC activity: the number of venture capital (VC) deals from PricewaterhouseCoopers Money Tree report that is based on data derived from Thompson Financials. The amount of VC activity varies between 0 and 1,535 deals, with an average of 99 deals per state in 2004 . This variable is highly skewed, with states such as California, Massachusetts, and New York receiving a bulk of the deals. ${ }^{16}$

\footnotetext{
${ }^{14}$ Bureau of Labor Statistics NAICS categories are classified as Technology Generators vs. Technology Employers. We use the first definition. Using the second definition gives us comparable results, although the coefficients are less precisely estimated since there are fewer ventures that are categorized as hi-tech using the second definition. In addition, we considered a hi-tech industry dummy based on the strata that Kauffman uses; there is no substantial change to our results.

${ }^{15}$ Defined as R\&D spending (from the National Science Foundation's Science and Technology Indicators) divided by gross state product (from the Bureau of Labor Statistics). As an alternative measure of innovation we used the number of patents by state, year, and industrial categories (NAICS code) (obtained from the U.S. Patent and Trademark Office). Our results are unchanged.

16 Using the amount of VC investment gives us the same result.
} 
Finally, state fixed-effects are used to control for time-invariant state characteristics not captured in the data. Industry fixed-effects use a 2-digit NAICS code to control for timeinvariant industry specific effects.

\section{Estimation Methodology and Results}

We use multi-nominal logit to investigate how asset specificity, information opacity, and entrepreneur attributes and startup characteristics are related to the financial structure of a startup in its founding year. The generalized form for the response probabilities for the model is given in the following equation:

$$
\begin{aligned}
& \mathrm{P}(y=j \mid X)=\mathrm{G}\left(\beta_{1}+\sum_{k=2}^{6} \beta_{k} \text { Asset_Specificity }_{k}+\sum_{l=7}^{10} \beta_{l} \text { Info__opacity }_{j l l}+\right. \\
& \left.\sum_{m=11}^{16} \beta_{m} \text { Entrepreneur_Attributes }_{m}+\sum_{p=12}^{14} \beta_{p} \text { Startup_Charac }_{p}+\sum_{r=15}^{18} \beta_{r} \text { Control_Charac }_{r}\right)
\end{aligned}
$$

For our main assessment of the KFS financial structure, we consider the four-way multinomial choice of financial source: for example, internal equity, internal debt, external equity, and external debt, and then the six-way decomposition that focuses on the types of external debt.

\subsection{Financial Structure Four Ways: Internal Debt/Equity vs. External Debt/Equity}

To investigate the financial structures common to startups we estimate the multinomial logit model in Table 2. The base type of finance is internal equity: owner, to which we compare internal debt: family and friends (column 1), external debt: bank/credit card/other (column 2) and external equity: VC/angel and other (column 3). We include state and industry (2-digit NAICS) controls along with our key variables of interest on assets, information opacity, and owner and venture characteristics. In the tables we present the raw coefficients, and for the discussion below we present the odds ratios based on the relevant tables.

With regard to the measures of asset specificity, we find that greater tangible assets increase the probability that the startup has both internal and external debt in its financial 
structure. Calculating odds ratios, we find that evaluated at the mean, a thousand dollar increase in physical assets increases the probability of using debt by approximately 3.4 percent. ${ }^{17}$ This is consistent with these assets having a higher liquidation value, making them superior as collateral for external loans or borrowing from friends and family. Higher business knowledge (as a measure of human capital, but also of potentially available collateral) reduces the probability of having external equity in the financial structure, consistent with the owners' using their other business assets as collateral for debt. In fact, a 1 unit increase in the business knowledge of the entrepreneur (say, if they have one more business entity already) decreases the probability of using external equity by 80 percent. Higher industry experience of the entrepreneur (as specific human capital) reduces the probability of using both internal and external debt: an increase of 1 unit (say, one year of experience) is associated with a 5 percentage point decrease in probability. This lower probability of debt use is consistent with lenders worrying that the entrepreneur could walk away from the startup's debt obligations. Higher intellectual property reduces the probability of using external debt to finance a startup, although this effect is not economically significant.

With regard to the variables measuring information opacity, firms led by teams are more likely to finance operations through the personal resources of the owners or, as expected, obtain external equity rather than finance through debt. Calculating the odds ratios, we find that a team-led startup is 43 percent less likely to use internal debt and 32 percent less likely to use external debt compared to internal equity. A home-office based startup is equally likely to use the owner's personal resources or external debt, and, as expected, is approximately 62 percent less likely to use external equity or borrow from family.

Consistent with other research, startups owned by African-American entrepreneurs have a lower probability of having any type of external finance, especially external equity, and instead finance their firms through personal resources. Based on odds ratios, we find that such businesses are 60 percent less likely to use external debt and 98 percent less likely to use

\footnotetext{
17 The mean for physical assets is $\$ 1764.40$.
} 
external equity, compared to using internal equity. In contrast to other research, women owners ${ }^{18}$ do not show a different financial structure from startups where the primary owner is male. U.S. citizen $^{19}$ and non-U.S. citizen entrepreneurs have similar startup financial structures. Ventures with older entrepreneurs (age) are less likely to finance their operations by borrowing from friends and family. College educated entrepreneurs are 22 percent more likely to have external debt as opposed to other forms of financing, and this may be because these entrepreneurs possess sufficient financial sophistication to allow them to successfully navigate bank and government loan programs. ${ }^{20}$

Firm characteristics are also influential in determining the financing used by startups. Incorporated firms and larger (size) startups have a greater probability of using external finance than sole proprietorships or small firms, which tend to be financed by internal sources.

State characteristics are also important. New ventures located in highly educated states tend to be financed by internal rather than external sources. Startups in larger states are less likely to borrow from friends and family. Startups in more innovative states are more likely to use external equity. Robust $V C$ activity in a state is associated with a higher likelihood of using external equity compared to internal equity, but also a higher probability of internal debt versus internal equity.

In summary, we find that new business ventures are more likely to have external debt financing if they have more physical assets and more business knowledge (as collateral) since these have a high liquidation value. Consistent with its low collateral value, startups with higher human capital embodied in the entrepreneur have a lower probability of using debt. Team-run startups are less likely to use debt finance, and consistent with their greater information, more likely to have external equity. Startups located in the entrepreneur's home are less likely to borrow from friends and family, and, consistent with their information opacity, are less likely to have external equity in their financial structure. Educated entrepreneurs are more likely to use debt financing, while African-American entrepreneurs are more likely to use

\footnotetext{
${ }^{18}$ Differs from Fay and Williams, 1991; Verheul and Hurik, 2001.

${ }^{19}$ Compares with Petersen and Rajan, 1994; Coleman and Cohn, 2000; Baum and Silverman, 2004; Chang, 2004.

${ }^{20}$ Consistent with (Bates, 1990; Cressy, 1996; Chandler and Hanks, 1998; Baum and Silverman, 2004; Astebro et al., 2005).
} 
their own resources to finance their businesses. External finance tends to be a significant share of the financial structure of large and incorporated startups.

\subsection{Financial Structure Six Ways: A Deeper Look into Debt in the Financial Structure}

The KFS reveals the wide variety of sources of startup finance. Using this rich detail, we can tease out more information about the financial structure of startups and how it is related to asset-specificity and information-opacity characteristics. The largest source of external funding is from external debt. Looking deeper into this category reveals that external debt comprises bank loans, credit card use, and other debt (such as government lending and loans from other businesses).

Table 3 looks more deeply into the type of external debt in the financial structure of startups, looking at a six-way decomposition of the financial structure of the startup: Owner equity is the base financial resource. The five other types of finance are: (i) internal debt and equity, that is, equity owned by family, and loans from friends, family, and employees, (ii) external debt: bank loan, (iii) external debt: personal or business credit card, (iv) external debt: other, such as loans from the government and other businesses, (v) equity: VCs and angel investors, and other sources.

The six-way decomposition of financial structure can be compared to the four-way decomposition. Startups with greater tangible assets are more likely to finance their operations through all types of debt, both internal and external. Other things being equal, as tangible capital increases by a thousand dollars (evaluated at the mean), new ventures are 5.7 percent more likely to use bank loans and 3.4 percent more likely to use credit cards to finance their operations than to use the owners' personal resources. Given entrepreneur industry experience or intellectual property in the startup, the lower probability of using external debt found in Table 2 can be traced to a decline in the probability of using credit card debt, although the effect is not economically significant. As in Table 2, an increase in business knowledge of the entrepreneur reduces the likelihood of external equity in the financial structure of the startup.

In Table 2, serial entrepreneurship and home-based office were not related to financial structure. However, in Table 3 we observe that serial entrepreneurs are equally likely to finance 
their businesses using their own resources, bank loans, or external equity, since more information is available about these entrepreneurs, which mitigates the information opacity problem. Additionally, based on odds ratios, we find that such a venture is 3.3 percent less likely to be financed by credit card debt and 2.6 percent more likely to be financed by other types of external debt such as government loans. ${ }^{21}$ These results are consistent with serial entrepreneurs having a wealth base from which to finance the new business, and with their being familiar with government loan programs, so that they tend not to use credit cards to finance the startup.

Table 2 showed that the financial structure of team startups was less likely than that of other startups to include debt. From Table 3 we find that the result is driven by credit card debt and other external loans. Team-run firms are 35 percent less likely than other startups to finance their operations using credit cards and 72 percent less likely to use nonbank loans compared to internal equity.

In Table 2, the home-office based startup was equally likely as other startups to use owner equity as external debt. Table 3 reveals that the main type of external debt used by the homebased startup is credit card debt. Entrepreneurs with home offices are 17 percent more likely to use credit card debt and 51 percent less likely to use nonbank external debt than other startups.

In Table 2 we saw that the financial structure of African-American owner startups was less likely to use external debt. Table 3 shows that this result comes from much less likely use of credit card or nonbank debt; African-American entrepreneurs are equally likely to use either their own resources or bank loans. Similar to the results in Table 2, the results in Table 3 show that the financial structure of women-owned startups does not differ from the norm for startups.

\subsection{The Hi-Tech Story}

The financial structure of hi-tech startups attracts substantial interest, particularly given the supposed role of angel investors and venture capital. In Table 4, we re-estimate the

\footnotetext{
${ }^{21}$ Compares to Delmar and Shane, 2006.
} 
multinomial logit model presented in Table 2, and add a hi-tech dummy and interactions between regressors and the hi-tech dummy. The hi-tech dummy captures the level effect and shows whether the overall financial structure of hi-tech startups differs from that of other startups. Significant interaction terms show whether the nature of assets, information opacity, and owner and firm characteristics interact differently with the financial structure of hi-tech startups than with the financial structure of all other startups.

From Table 4 we find that the hi-tech dummy is negative and significant for internal debt and positive and significant for external equity. This implies that hi-tech startups are less likely to borrow from friends and family and are more likely to use external equity financing as opposed to their own resources. Thus, the overall financial structure of the hi-tech startup does differ from the startup norm.

The interactions between the hi-tech dummy and regressors suggest specific factors underpinning the different financial structure of hi-tech startups. Business knowledge of the hitech entrepreneurs (a proxy for collateral value of other businesses) increases the probability of borrowing from friends and family (column 1b) - these may be the true angel investors, since the likelihood of the hi-tech startups using external equity (coded as VC/angel) is lower than for non-hi-tech startups (column 3b). Additionally, we find that in hi-tech startups, serial entrepreneurs are less likely to use either external debt (column $2 b$ ) or equity (column $3 b$ ) than internal resources.

With regard to intellectual property, in column 2a the coefficient is negative and significant, implying that firms with more intellectual property are less likely to use external debt than startups in traditional sectors. However, from column $2 b$, the interaction term is positive and significant, implying that startups with intellectual property are more likely to use external debt compared to the owners' personal resources. For hi-tech startups, patents may signal a future revenue stream that can help to secure external loans. Overall, the magnitude of the positive coefficient swamps the negative effect, implying that overall the effect of intellectual property on the use of external financing is positive.

There is great heterogeneity in the relationship between owner attributes and the financial structure of startups in hi-tech versus all other business sectors. For example, we find 
that hi-tech startups with African-American entrepreneurs are less likely than startups in other industries to borrow from friends and family (column 1b). The level effect and the interaction effect wash out for external equity (column 3a and 3b), which is not the case for their non-black counterparts. Women-owned hi-tech startups do not differ in financial structure from the hitech norm. U.S. citizen startups in the hi-tech sector are more likely than non-U.S. citizen startups to borrow from friends and family (column 1b).

The financial structure of hi-tech startups also differs from the startup norm with respect to the education and age of the entrepreneur. We find that for external debt, the level effect of education is positive, while the interaction term between the education dummy and the hi-tech dummy is negative and significant. This implies that the financial structure of hi-tech startups started by college-educated entrepreneurs has less external debt than other startups do. Hi-tech startups with older entrepreneurs are less likely than other startups to use external equity.

This is one of the few papers that document how the financial structure of hi-tech startups differs from that of other startups along the dimensions of entrepreneurial human capital, intellectual property, race, education, and citizenship of the entrepreneur.

\section{Conclusion}

Startups are likely to suffer from greater information opacity and higher asset specificity than large established firms, or even small ongoing firms. For startups, the existence of human capital-specific assets, coupled with small levels of traditional tangible assets that can serve as

collateral, and the lack of information and reputation suggest constraints on borrowing from external sources. Therefore, we should expect to observe a higher overall dependence on internal sources of funds in the financial structure of startups. However, because startups may face financial constraints, the entrepreneur will look to augment personal resources. Using the Kauffman Firm Survey of new businesses, we investigate how information opacity and asset specificity are related to the initial financial structure of startups, controlling for owner's attributes, and firm, sector, and spatial characteristics. 
Consistent with theoretical underpinnings based on asset specificity, we find that startups with more tangible assets as potential collateral are more likely to use external debt in the financial structure, since these assets have a high liquidation value. Entrepreneurs with other businesses as collateral are less likely to give up control to external equity investors. On the other hand, all else equal, startups with higher human capital embodied in the entrepreneur or more intellectual property assets have a lower probability of using debt than other startups, consistent with the higher asset specificity and lower collateral value of these assets.

In terms of information opacity, startups located in the entrepreneur's home are the most opaque and their financial structure is dominated by credit card debt. Team-run startups are less likely to use debt finance, particularly credit cards and other external loans and, consistent with their greater personal resources and available information, more likely to have internal and external equity in their financial structure. Serial entrepreneurs are equally likely to finance their businesses using their own resources, bank loans, or external equity, since more information is available about these entrepreneurs, which mitigates the information opacity problem.

In terms of owner attributes, some, but importantly not all, of our findings mirror the research on ongoing small businesses. Educated entrepreneurs are more likely to use debt financing. African-American entrepreneurs are more likely to use their own resources to finance their business and less likely to use credit card or nonbank debt. An important finding is that the financial structure of women-owned startups does not differ from that of maleowned startups, controlling for many other attributes.

Regional factors and local conditions relate to the financial structure of startups. Areas with better-educated resident populations may have greater personal resources to finance startups using internal debt. Startups in innovative states and states with higher venture capital activity have a greater probability of having external equity in their financial structure. Startups in larger states have a higher probability of having bank loans in their financial structure.

We also find significant dissimilarities in the financial structure of hi-tech startups and startup in other sectors. Some of the biggest differences can be traced to the relationship between financial structure and race, citizenship, and business knowledge. 


\section{References}

Acs, Z. J. \& Audretsch, D. B. (1989). “Small Firm Entry in U.S. Manufacturing,” Economica, Vol. 56(222), pp. $255-265$.

Astebro, T. \& Bernhardt, I. (2005). “The Winner's Curse of Human Capital," Small Business Economics, Vol. 24, pp. 63- 78 .

Audretsch, D. B., Lehmann, E. E. \& Plummer, L. A. (2009). “Agency and Governance in Strategic Entrepreneurship," Entrepreneurship Theory and Practice, January, pp. 150- 166.

Avery, R. B., Bostic, R. W. \& Samolyk, K. A. (1998). “The Role of Personal Wealth in Small Business Finance," Journal of Banking \& Finance, Vol. 22, pp. 1019- 1061.

Balakrishna, S. 7 Fox, I. (1993). "Asset Specificity, Firm Heterogeneity and Capital Structure," Strategic Management Journal, Vol. 14(1), pp. 3-16.

Baskin, J., (1989). “An Empirical Test of the Pecking Order Hypothesis," Financial Management, Vol. 18, pp. 26- 35 .

Bates, T. (1990). “Entrepreneur Human Capital Inputs and Small Business Longevity," Review of Economics and Statistics, Vol. 72(4), pp. 551- 559.

(1997a). "Financing Small Business Creation: The Case of Chinese and Korean Immigrant Entrepreneurs," Journal of Business Venturing, Vol. 12, pp. 109- 124.

(1997b). “Unequal Access: Financial Institution Lending to Black- and White-Owned Small Business Start-Ups," Journal of Urban Affairs, Vol. 19(4), pp. 487- 495.

Baum, J. A.C. \& Silverman, B. S. (2004). “Picking Winners or Building Them? Alliance, Intellectual, and Human Capital as Selection Criteria in Venture Financing and Performance of Biotechnology Startups," Journal of Business Venturing, Vol. 19, pp. 411- 436.

Berger, A. M. \& Udell, G. F. (1995). “Relationship Lending and Lines of Credit in Small Firm Financing," Journal of Business, Vol. 68(3), pp. 351-381.

\&___ (2003). "Small Business and Debt Finance," Handbook of Entrepreneurship Research, (eds.) Acs, Z. J. \& Audretsch D.B., pp. 299- 328, .Kluwer Academic Publishers. Great Britain.

Bruno, A. V. \& Tyebjee, T. T. (1985). “The Entrepreneur's Search for Capital," Journal of Business Venturing, Vol. 1(1), pp. 61- 74.

Cassar, G. (2004). "The Financing of Business Start-Ups," Journal of Business Venturing, Vol. 19(2), pp. 261- -283. 
Chandler, G. N. \& Hanks, S. H. (1998). “An Examination of the Substitutability of Founders' Human and Financial Capital in Emerging Business Ventures," Journal of Business Venturing, Vol. 13, pp. 353-369.

Chang, S. J. (2004). "Venture Capital Financing, Strategic Alliances, and the Initial Public Offerings of Internet Startups," Journal of Business Venturing, Vol.19, pp. 721- 741.

Coleman, S, \& Cohn, R. (2000). “Small Firms' Use of Financial Leverage: Evidence from the 1993 National Survey of Small Business Finances," Journal of Business Entrepreneurship, Vol. 12(3), pp. 81- 98 .

Cressy, Robert, 1996. "Are Business Startups Debt-Rationed?" Economic Journal, Royal Economic Society, Vol. 106 (438), pp. 1253-- 70, September.

Delmar, F. \& Shane, S. (2006). "Does Experience Matter? The Effect of Founding Team Experience on the Sales of Newly Founded Firms," Strategic Organization, Vol. 4(3), pp. 215247.

Fay, M. \& Williams, L. (1991). “Sex of Applicant and the Availability of Business 'Start-Up' Finance," Australian Journal of Management, Vol. 16(1).

Haltiwanger, John C., Ron S. Jarmin, Javier Miranda (2010). “Who Creates Jobs? Small vs. Large vs. Young," NBER working Paper 16300, (August).

Hart, O. \& Moore, J. A. (1995). “A Theory of Debt Based on the Inalienability of Human Capital," Quarterly Journal of Economics, Vol. 109(4), pp. 841-- 879.

Huyghebaert, N. \& Van de Gucht, L. M. (2007). “The Determinants of Financial Structure: New Insights from Business Start-Ups," European Financial Management, Vol. 13(1), pp. 101-133.

Kane, Tom (2010). "The Importance of Startups in Job Creation and Job Destruction," Kauffman Foundation Research Series: Firm Formation and Economic Growth (July).

Klein, B., Crawford, R. \& Alchian, A. (1978). “Vertical Integration, Appropriable Rents and The Competitive Contracting Process,",Journal of Law and Economics, Vol. 21, pp. 297-- 326.

Kochhar, R. (1996). “Explaining Firm Capital Structure: The Role of Agency Theory vs. Transaction Cost Economics," Strategic Management Journal, Vol. 17, pp. 713- 728.

Manigart, S. \& Struyf, C. (1997). “Financing High Technology Startups in Belgium: An Explorative Study," Small Business Economics, Vol. 9(2), pp. 125- 135.

Modigliani, F. \& Miller, M. H. (1958). “The Cost of Capital, Corporation Finance and the Theory of Investment," American Economic Review, Vol. 48, pp. 261- 297. 
Paulson, A. L. \& Townsend, R. (2004). “Entrepreneurship and Financial Constraints in Thailand" Journal of Corporate Finance, Vol. 10, pp. 229- 262.

Petersen, M. A. \& Rajan, R. G. (1994). “The Benefits of Lending Relationships: Evidence from Small Business Data," Journal of Finance, Vol. XLIX (1), pp. 3-37.

PricewaterhouseCoopers (2009). "Money Tree Report," PricewaterhouseCoopers https://www.pwcmoneytree.com/MTPublic/ns/index.jsp

Saxenian, AnnaLee, Silicon Valley's New Immigrant High-Growth Entrepreneurs (2002). Economic Development Quarterly, Vol. 16, Issue 1, p. 20- 31 2002. Available at SSRN: http://ssrn.com/abstract $=1495505$

Scholtens, B. (1999). “Analytical Issues in External Financing for SBEs," Small Business Economics, Vol. 12(2), pp. 137- 148.

Smallbone, D., Ram, M., Deakins, D. \& Baldock, R. (2003). “Access to Finance by Ethnic Minority Businesses in the UK." International Small Business Journal, Vol. 21(3), pp. 291- 314.

Stangler, Dane (2010). "High-Growth Firms and the Future of the American Economy," Kauffman Foundation Research Series: Firm Formation and Economic Growth (March).

Verheul, I. \& Hurik, R. (2001). “Start-Up Capital: Does Gender Matter?” Small Business Economics, Vol. 16, pp. 329-345.

Vincente-Lorente, J. D. (2001). "Specificity and Opacity as Resource-Based Determinants of Capital Structure: Evidence from Spanish Manufacturing Firms," Strategic Management Journal, Vol. 22, pp. 157-177.

Williamson, O. E. (1975). Market and Hierarchies: Analysis and Antitrust Implications, Free Press New York.

(1985). The Economic Institutions of Capitalism, Free Press, New York. 
TABLE 1A

Financial Structure 2004

\begin{tabular}{|l|l|l|l|l|l|l|}
\hline & Obs & $\begin{array}{l}\text { Mean } \\
(\text { Real \$) }\end{array}$ & $\begin{array}{l}\text { Median } \\
(\text { Real \$) }\end{array}$ & SD & Min & Max \\
\hline Amt. Total Financing & 4201 & 165660 & 13250 & $3.53 \mathrm{M}$ & 0 & $224 \mathrm{M}$ \\
\hline Amt. of External Financing & 4201 & 94488 & 300 & $2.10 \mathrm{M}$ & 0 & $133 \mathrm{M}$ \\
\hline Amt. of Internal Financing & 4201 & 71172 & 7500 & $1.47 \mathrm{M}$ & 0 & $92 \mathrm{M}$ \\
\hline Amt. Internal Equity & 4201 & 46295 & 6000 & $0.43 \mathrm{M}$ & 0 & $25 \mathrm{M}$ \\
\hline Amt. Internal Debt & 4201 & 24876 & 0 & $1.39 \mathrm{M}$ & 0 & $90 \mathrm{M}$ \\
\hline Amt. of External Debt & 4201 & 66992 & 0 & $1.46 \mathrm{M}$ & 0 & $93 \mathrm{M}$ \\
\hline Amt. of External Equity & 4201 & 27496 & 0 & $0.71 \mathrm{M}$ & 0 & $40 \mathrm{M}$ \\
\hline & Obs & Mean (\%) & Median (\%) & SD & Min & Max \\
\hline \% of Internal Financing in Total & 4201 & 68.05 & 86.96 & 0.370 & 0 & 1 \\
\hline \% of Equity in Internal Financing & 4201 & 93.51 & 100 & 0.220 & 0 & 1 \\
\hline \% of Debt in External Financing & 4201 & 96.10 & 100 & 0.186 & 0 & 1 \\
\hline \% of Int. Equity in Total Amt. & 4201 & 64.32 & 81.05 & 0.388 & 0 & 1 \\
\hline \% of Int. Debt in Total Amt. & 4201 & 3.73 & 0 & 0.154 & 0 & 1 \\
\hline \% of Ext. Debt in Total Amt. & 4201 & 30.41 & 9.09 & 0.365 & 0 & 1 \\
\hline \% of Ext. Equity in Total Amt. & 4201 & 1.54 & 0 & 0.106 & 0 & 1 \\
\hline
\end{tabular}

TABLE 1B

Summary Statistics for Dependent Variables - 2004

\begin{tabular}{|l|l|l|l|}
\hline Discrete Variables & Obs. & Ones & $\%$ \\
\hline Four Choices & & & \\
\hline Internal Equity Dummy & 4201 & 1077 & 25.64 \\
\hline Internal Debt Dummy & 4201 & 127 & 3.02 \\
\hline External Debt Dummy & 4201 & 2941 & 70.01 \\
\hline External Equity Dummy & 4201 & 56 & 1.39 \\
\hline Six Choices & & & \\
\hline $\begin{array}{l}\text { Owner's Personal Resources } \\
\text { (Equity \& Debt) }\end{array}$ & 4023 & 1070 & 26.60 \\
\hline $\begin{array}{l}\text { Financing from Family/ Friends/ } \\
\text { Employees (Equity \& Debt) }\end{array}$ & 4023 & 131 & 3.26 \\
\hline Bank Debt & 4023 & 224 & 5.57 \\
\hline Credit Card Debt & 4023 & 2343 & 58.24 \\
\hline Loans from Govt., Others. & 4023 & 199 & 4.95 \\
\hline $\begin{array}{l}\text { External Equity Financing } \\
\text { (VC/Angel, Other) }\end{array}$ & 4023 & 56 & 1.39 \\
\hline
\end{tabular}


TABLE 1C

Summary Statistics for Explanatory Variables - 2004

\begin{tabular}{|l|l|l|l|l|l|}
\hline Independent Variables & & & & & \\
\hline Assets & & & & & \\
\hline & Mean & Median & SD & Min & Max \\
\hline Tangible Assets (Log Amount) & 7.475 & 9.558 & 6.607 & -9.210 & 19.431 \\
\hline Human Capital 1: Business Knowledge & 0.240 & 0 & 0.519 & 0 & 6 \\
\hline Human Capital 2: Industry Experience & 16.824 & 14 & 15.592 & 0 & 150 \\
\hline Human Capital 3: Share of R\&D Personnel & 0.380 & 0 & 0.620 & 0 & 5 \\
\hline Intellectual Property & 1.345 & 0 & 7.738 & 0 & 103 \\
\hline Information Opacity & & & & & \\
\hline Serial Entrepreneurship & 1.375 & 0 & 4.518 & 0 & 140 \\
\hline & Ones & Zeros & $\%$ Ones & Obs. & \\
\hline Team Run Business Dummy & 1224 & 2977 & 29.14 & 4201 & \\
\hline Home Office Dummy & 2458 & 1743 & 58.51 & 4201 & \\
\hline Owner Attributes & & & & & \\
\hline Black Primary Owner Dummy & 355 & 3846 & 8.45 & 4201 & \\
\hline Woman Primary Owner Dummy & 1103 & 3098 & 26.26 & 4201 & \\
\hline Education Level Dummy & 2525 & 1676 & 60.10 & 4201 & \\
\hline US Citizen Primary Owner Dummy & 4052 & 149 & 96.45 & 4201 & \\
\hline & Mean & Median & SD & Min & Max \\
\hline Age of Primary Owner & 45.022 & 44 & 10.887 & 17 & 87 \\
\hline Venture Characteristics & & & & & \\
\hline Size of Venture (Log No. of Employees) & 0.345 & 0 & 0.664 & 0 & 4.318 \\
\hline & Ones & Zeros & $\%$ Ones & Obs. & \\
\hline Incorporated Company Dummy & 2714 & 1487 & 64.60 & 4201 & \\
\hline Hi-Tech Dummy & 587 & 3614 & 13.97 & 4201 & \\
\hline & & & & & \\
\hline & Mean & Median & SD & Min & Max \\
\hline $\begin{array}{l}\text { Highly Educated Population Size (Log No } \\
\text { Graduate Students) }\end{array}$ & 9.485 & 9.423 & 0.919 & 6.269 & 10.787 \\
\hline $\begin{array}{l}\text { Innovative Capacity of State (R\&D } \\
\text { Intensity) }\end{array}$ & 2.418 & 2.044 & 1.291 & 0.391 & 7.427 \\
\hline State Size (Log Population) & 15.933 & 15.955 & 0.889 & 13.114 & 17.363 \\
\hline VC Activity in State (No. of VC Deals) & 251.19 & 99 & 458.99 & 0 & 1535.75 \\
\hline & & & & & \\
\hline
\end{tabular}


TABLE 2

Financial Structure: Four-Way

\begin{tabular}{|l|l|l|l|}
\hline Base: Internal Equity & $\begin{array}{l}\text { Internal } \\
\text { Debt }\end{array}$ & $\begin{array}{l}\text { External } \\
\text { Debt }\end{array}$ & $\begin{array}{l}\text { External } \\
\text { Equity }\end{array}$ \\
\hline Coefficient & 1 & 2 & 3 \\
\hline Assets & & & \\
\hline Tangible Assets & $0.056^{* * *}$ & $0.057^{* * *}$ & 0.018 \\
\hline Human Capital 1: Business Knowledge & -0.006 & -0.222 & $-1.597^{*}$ \\
\hline Human Capital 2: Industry Experience & $-0.032^{* *}$ & $-0.012^{* *}$ & -0.009 \\
\hline Human Capital 3: Share of R\&D Personnel & 0.090 & 0.038 & 0.100 \\
\hline Knowledge Capital & -0.016 & $-0.010^{*}$ & 0.017 \\
\hline Information Opacity & & & \\
\hline Serial Entrepreneur & -0.033 & -0.004 & 0.028 \\
\hline Team Run Business Dummy & $-1.001^{* *}$ & $-0.378^{* * *}$ & -0.668 \\
\hline Home Office Dummy & $-0.961^{* * *}$ & 0.104 & $-1.014^{*}$ \\
\hline Owner Attributes & & & \\
\hline Black Primary Owner Dummy & -0.144 & $-0.891^{* * *}$ & $-3.717^{* * *}$ \\
\hline Woman Primary Owner Dummy & -0.159 & 0.026 & 0.056 \\
\hline Age of Primary Owner & $-0.032^{* * *}$ & -0.001 & 0.024 \\
\hline Education Level Dummy & -0.130 & $0.218^{* *}$ & 0.548 \\
\hline US Citizen Primary Owner Dummy & -0.491 & 0.092 & -0.698 \\
\hline Venture Characteristics & & & \\
\hline Size of Venture & 0.158 & $0.480^{* * *}$ & $0.790^{* * *}$ \\
\hline Incorporated Company Dummy & -0.278 & $0.374^{* * *}$ & $21.016^{* * *}$ \\
\hline State Characteristics (Lag 1 Yr.) & & & \\
\hline Highly Educated Population Size & -0.646 & $-0.772^{*}$ & $-4.577^{* * *}$ \\
\hline Innovative Capacity of State & 0.104 & 0.138 & $5.020^{* * *}$ \\
\hline State Size & $-0.855^{* *}$ & 0.602 & 0.239 \\
\hline VC Activity in State & $0.018^{* * *}$ & 0.0002 & $0.017^{* * *}$ \\
\hline Relevant Statistics & 4201 & & \\
\hline Observations & & 4201 & 4201 \\
\hline Non & & \\
\hline
\end{tabular}

Note: Estimation using a multinomial logit regression, with survey weights provided by the KFS survey data. Base category: Internal equity. Regression controls include: Industry (2 digit NAICS) and State fixed effects. Funding decomposition: 127 startups funded primarily with internal debt, 2941 startups funded primarily with external debt, 56 startups primarily with external equity. Year=2004. ' '*', '**' and '***' denote significance at 10 percent, 5 percent and 1 percent respectively. 
TABLE 3

Financial Structure: Six Way

\begin{tabular}{|c|c|c|c|c|c|}
\hline $\begin{array}{l}\text { Base: Owner's Equity } \\
\text { and Debt }\end{array}$ & $\begin{array}{l}\text { Other Internal } \\
\text { Debt and Equity }\end{array}$ & $\begin{array}{l}\text { Bank } \\
\text { Debt }\end{array}$ & $\begin{array}{l}\text { Credit } \\
\text { Card Debt }\end{array}$ & $\begin{array}{l}\text { Other } \\
\text { Debt }\end{array}$ & $\begin{array}{l}\text { External } \\
\text { Equity }\end{array}$ \\
\hline Coefficient & Column 1 & Column 2 & Column 3 & Column 4 & Column 5 \\
\hline \multicolumn{6}{|l|}{ Assets } \\
\hline Tangible Assets & $0.068 * * *$ & $0.094 * * *$ & $0.055 * * *$ & $0.087 * * *$ & 0.216 \\
\hline $\begin{array}{l}\text { Human Capital 1: } \\
\text { Business Knowledge }\end{array}$ & 0.002 & -0.101 & -0.181 & -0.165 & $-1.616^{*}$ \\
\hline $\begin{array}{l}\text { Human Capital 2: } \\
\text { Industry Experience }\end{array}$ & -0.018 & -0.017 & $-0.010^{*}$ & -0.018 & -0.012 \\
\hline $\begin{array}{l}\text { Human Capital 3: Sh. } \\
\text { of R\&D Personnel }\end{array}$ & 0.011 & -0.187 & 0.057 & 0.240 & 0.078 \\
\hline Intellectual Property & -0.014 & -0.034 & $-0.010 *$ & -0.006 & 0.016 \\
\hline \multicolumn{6}{|l|}{ Information Opacity } \\
\hline Serial Entrepreneur & -0.038 & -0.0001 & $-0.033^{*}$ & $0.026 * *$ & 0.029 \\
\hline Team Run Bus. Dum. & $-0.986 * * *$ & -0.110 & $-0.350 * *$ & $-0.724 * *$ & -0.708 \\
\hline Home Office Dum. & $-0.721 * * *$ & -0.045 & $0.174 *$ & $-0.509 * * *$ & $-0.983 *$ \\
\hline \multicolumn{6}{|l|}{ Owner Attributes } \\
\hline Black Owner Dum. & 0.022 & -0.482 & $-0.882 * * *$ & $-0.748 * *$ & $-3.694 * * *$ \\
\hline Woman Owner Dum. & -0.096 & -0.258 & 0.064 & -0.324 & 0.037 \\
\hline Age of Primary Owner & $-0.029 * * *$ & 0.003 & -0.001 & 0.009 & 0.027 \\
\hline Education Level Dum. & -0.102 & -0.047 & $0.247 * * *$ & 0.176 & 0.492 \\
\hline US Cit. Owner Dum. & -0.529 & 0.003 & 0.030 & 0.206 & -0.716 \\
\hline \multicolumn{6}{|l|}{ Venture Characteristics } \\
\hline Size of Venture & 0.221 & $0.680^{* * *}$ & $0.430^{* * *}$ & $0.921 * * *$ & $0.844^{* * *}$ \\
\hline Incorp. Co. Dum. & -0.052 & $0.635^{* *}$ & $0.378^{* * * *}$ & 0.149 & $20.910 * * *$ \\
\hline \multicolumn{6}{|c|}{ State Characteristics(Lag: 1 Year) } \\
\hline Highly Edu. Pop. Size & -0.782 & $-1.113 * *$ & $-0.796 *$ & $-4.794 * * *$ & $-5.033 * * *$ \\
\hline Innov. Cap. of State & 0.126 & $0.972^{* * *}$ & 0.125 & $4.420^{* * *}$ & $5.122 * * *$ \\
\hline State Size & -0.742 & $7.574 * * *$ & 0.535 & $1.703 * * *$ & 0.217 \\
\hline VC Activity in State & $0.018 * * *$ & $-0.011 * * *$ & 0.0004 & $0.015 * * *$ & $0.018 * * *$ \\
\hline \multicolumn{6}{|l|}{ Relevant Statistics } \\
\hline Observations & 4023 & 4023 & 4023 & 4023 & 4023 \\
\hline
\end{tabular}

Note: Estimated using a multinomial logit regression, with survey weights provided by the KFS survey data. Base category: Owner's personal resources (both debt and equity). Regression controls include: Industry (2 digit NAICS) and state fixed effects. Funding decomposition: 131 startups funded primarily by friends/family or employees, 224 startups funded primarily with bank debt, 2343 use credit card debt, 199 use other external loans such as those from the government, 56 are financed using either VC or angel financing, or by other external equity. Year=2004. '*', '**' and '***' denote significance at 10 percent, 5 percent and 1 percent respectively. 
TABLE 4

The Hi-Tech Story

\begin{tabular}{|c|c|c|c|c|c|c|}
\hline \multirow{2}{*}{\begin{tabular}{|l|} 
Base Choice: \\
Internal Equity \\
\end{tabular}} & \multicolumn{2}{|c|}{ Internal Debt } & \multicolumn{2}{|c|}{ External Debt } & \multicolumn{2}{|c|}{ External Equity } \\
\hline & 1a & $1 \mathrm{~b}$ & 2a & $2 \mathrm{~b}$ & 3a & $3 \mathrm{~b}$ \\
\hline Coefficient & Level & Interaction & Level & Interaction & Level & Interaction \\
\hline \multicolumn{7}{|l|}{ Assets } \\
\hline Tangible Assets & $0.057 * * *$ & -0.053 & $0.057 * * *$ & 0.007 & 0.017 & 0.027 \\
\hline $\begin{array}{l}\text { Human Cap. 1: } \\
\text { Bus. Knowledge }\end{array}$ & 0.004 & $34.201 * * *$ & $-0.233^{*}$ & 0.365 & $-1.624 *$ & $-30.456 * * *$ \\
\hline $\begin{array}{l}\text { Human Cap. 2: } \\
\text { Industry Experience }\end{array}$ & $-0.031 * *$ & -0.055 & $-0.012 * *$ & -0.016 & -0.006 & -0.027 \\
\hline $\begin{array}{l}\text { Human Cap. 3: Sh. } \\
\text { of R\&D Personnel }\end{array}$ & 0.090 & -0.006 & 0.040 & -0.040 & 0.133 & -0.252 \\
\hline Intellect. Property & -0.016 & -0.223 & $-0.011 *$ & $0.048 * *$ & 0.018 & 0.032 \\
\hline \multicolumn{7}{|c|}{ Information Opacity } \\
\hline $\begin{array}{l}\text { Serial } \\
\text { Entrepreneur }\end{array}$ & -0.028 & -0.147 & -0.002 & $-0.057^{*}$ & 0.034 & $-0.053^{*}$ \\
\hline $\begin{array}{l}\text { Team Run Bus. } \\
\text { Dum. }\end{array}$ & $-1.021^{* *}$ & 1.225 & $-0.387 * * *$ & 0.147 & -0.725 & 0.730 \\
\hline Home Off. Dum. & $-0.964 * * *$ & 0.398 & 0.102 & 0.166 & $-0.986 *$ & -1.582 \\
\hline \multicolumn{7}{|l|}{ Owner Attributes } \\
\hline Black Owner. & -0.143 & $-34.801 * * *$ & $-0.899 * * *$ & $1.020 *$ & $-25.086 * * *$ & $25.878 * * *$ \\
\hline Woman Owner & -0.155 & -0.146 & 0.026 & 0.079 & 0.089 & -0.453 \\
\hline Age Pri Owner & $-0.033 * * *$ & 0.060 & -0.001 & 0.011 & 0.028 & $-0.056^{*}$ \\
\hline Education Level & -0.129 & 0.423 & $0.229 * *$ & $-0.742 * * *$ & 0.564 & -0.623 \\
\hline US Citizen Own. & -0.515 & $19.322 * * *$ & 0.098 & -0.351 & -0.794 & 2.037 \\
\hline \multicolumn{7}{|c|}{ Venture Characteristics } \\
\hline High Tech Dum. & $-21.934 * * *$ & & 0.432 & & $4.643 * * *$ & \\
\hline Size of Venture & 0.165 & -0.437 & $0.484^{* * *}$ & -0.144 & $0.806 * * *$ & -0.357 \\
\hline Incorp. Co. Dum. & -0.267 & -0.495 & $0.374 * * *$ & -0.030 & $21.769 * * *$ & -3.343 \\
\hline \multicolumn{7}{|c|}{ State Characteristics(Lag 1 Year) } \\
\hline Hi. Edu. Pop. Size & -0.632 & & $-0.769 *$ & & $-4.220 * * *$ & \\
\hline Innov. Cap. of State & 0.101 & & 0.137 & & $4.894 * * *$ & \\
\hline State Size & $-0.722^{* *}$ & & 0.602 & & 0.390 & \\
\hline VC Activ. in State & $0.017 * * *$ & & 0.0002 & & $0.016 * * *$ & \\
\hline \multicolumn{7}{|l|}{ Relevant Statistics } \\
\hline Observations & 4201 & & 4201 & & 4201 & \\
\hline
\end{tabular}

Note: Estimated using multinomial logit, with survey weights provided by the KFS survey data. Base category: Internal equity. Regression controls include: Industry (2 digit NAICS) and state fixed effects. 127 startups primarily funded by internal debt, 2941 startups funded primarily with external debt, 56 startups funded primarily with external equity. Year=2004. ‘*’, ‘**’ and ‘***’ denote significance at 10 percent, 5 percent and 1 percent respectively. 